\title{
Can exporting SMEs benefit from extending longer payment periods?
}

\section{Saara Julkunen*, Markus Mättö, Mervi Niskanen and Max Niskanen}

\author{
Business School, \\ University of Eastern Finland, \\ Microkatu 1 E, 70211 Kuopio, Finland \\ Email: saara.julkunen@uef.fi \\ Email: markus.matto@uef.fi \\ Email: mervi.niskanen@uef.fi \\ Email: niskanenmax@gmail.com \\ *Corresponding author
}

\begin{abstract}
This study investigates whether a connection exists between extending trade credit and firm performance after controlling for the degree of internationalisation, when measured by the scope of exporting activities in a sample of Finnish SMEs. While previous studies extensively explored the connections between performance and trade credit, as well as performance and internationalisation, to our knowledge, this is the first study to examine their combined effect. Our main results imply that, while domestic firms have a negative relationship between trade receivables and profitability, exporting firms benefit from longer collection periods. Moreover, when examined separately, there is a negative connection between extending trade credit and firm performance, as well as between internationalisation and firm performance. We contribute to previous literature by suggesting that previously observed results between trade credit and firm performance may be driven by the export activities patterns of sample firms. The results imply that, contrary to expectations, exporting firms benefit from longer outstanding sales periods.
\end{abstract}

Keywords: trade credit; terms of trade; days sales outstanding; DSO; exporting firms; export sales; internationalisation; performance; profitability; small and medium-sized enterprises; SMEs.

Reference to this paper should be made as follows: Julkunen, S., Mättö, M., Niskanen, M. and Niskanen, M. (2021) 'Can exporting SMEs benefit from extending longer payment periods?', Int. J. Export Marketing, Vol. 4, No. 3, pp.306-323.

Biographical notes: Saara Julkunen is an Associate Professor in International Sales and Head of the Business School at University of Eastern Finland. Her research and teaching focus on international sales, sales management, customer-seller relationship development, inter-organisational collaboration and entrepreneurship.

Markus Mättö holds a DSc in Economics. He works at the University of Eastern Finland as a University Lecturer in Accounting and Finance. His research interests are corporate finance and auditing. 
Mervi Niskanen is a Professor of Finance at the University of Eastern Finland. Her research interests include corporate finance, short-term financial management, relationship lending, corporate governance, auditing, international finance as well as accounting and finance in family firms.

Max Niskanen was a researcher at the University of Eastern Finland Business School, and he is currently employed as Director, Consulting IP at CGI Finland, creating export business for a family of existing software products. His research interests are sales management, rapidly internationalizing SMEs and international business.

\section{Introduction}

Today, business management is increasingly complex due to growing international competition and higher financial requirements. Due to the complexity of export markets creating competitive stress, more attention should be paid to how small firms can develop their export performance (Brache and Felzensztein, 2019). Interestingly, trade credit has been identified as one important determinant of firm performance in boardroom discussions. However, business research has paid little attention to the relationship between trade credit and a firm's performance related to internationalisation in general and export activities at the firm level. Therefore, a study on the effect of trade credit on the relationship between the degree of internationalisation and performance is necessary. This study investigates the relationship between trade credit and firm performance in Finnish small and medium-sized enterprises (hereafter, SMEs) after controlling for the degree of internationalisation as measured by the firms' export activities.

Trade credit is defined as a business-to-business (B2B) agreement in which customers can purchase goods on account with delayed cash payments (Niskanen and Niskanen, 2006). From the seller's perspective, it is an account receivable; from the buyer's perspective, it is an account payable, where the account will be paid no later than the due date. Usually, businesses operating with trade credits will give buyers between 30 and 90 days to pay for their purchases. During the last three decades, the usage of trade credit in preference to bank loans as a source of funds has increased. Trade credit has become an important source of funds for companies of all sizes (Demirgüç-Kunt and Maksimovic, 2001; Petersen and Rajan, 1997). Differences in trade credit between industries have often been explored, as has their effect on the performance of different companies, such as SMEs. However, researchers disagree when it comes to the usage of trade credit. In previous literature, trade credit has been divided into those dealing with marketing motivations, financial motivations, transaction costs and contract compliance (Summers and Wilson, 2003). Furthermore, the concept of information asymmetry (Akerlof, 1970) often plays a major role in the investigation of trade credit. Several studies suggest that there is a negative relationship between trade credit and performance (Charitou et al., 2010; Deloof, 2003; Lazaridis and Tryfonidis, 2006; Nazir and Afza, 2009; Raheman and Nasr, 2007; Shin and Soenen, 1998). Additionally, the results of Tran et al. (2017) indicate that aggressive trade credit management can boost profitability. Tran et al. (2017) also found that the management of trade credit is more crucial in SMEs, probably because of restrictions on access to long-term funding (Petersen and Rajan, 1997). Essentially, firms want to ensure a profit and avoid 
unmanageable risk. Therefore, the most important aspect of managing trade credit is to find an optimal balance between accounts receivable, inventories and accounts payable by considering both the risks and efficiencies (Nazir and Afza, 2009).

In the absence of sustainable, satisfactory performance outcomes, a firm will not survive; hence, performance is the single most important dimension of its overall operation. The degree of internationalisation has also been shown to be linked to performance (Thomas and Eden, 2004). The link between profitability and internationalisation has been explained by, for example, organisational learning (Calof and Beamish, 1995), an increase in sales (Kuivalainen and Sundqvist, 2007) and the growth of customer and partner networks (De Noni and Apa, 2015). Timeframes for the definition of profitability have also been discussed, which range from short to extremely long. Moreover, the length of the timeframe under study has apparently influenced the models explaining the link between internationalisation and performance (Pangarkar, 2008; Ruigrok et al., 2007; Thomas and Eden, 2004). While few studies have investigated the link between internationalisation, trade credit and firm performance, Engemann et al. (2014) suggest that trade credit can be seen as an integral part of international sales processes, and therefore, should also play an important role in international trade.

This study contributes to the previous literature in several ways. First, we use a unique database that includes firm-level data from small and medium-sized Finnish firms. Because firm-level data on SMEs' export activities are not easily available, our findings offer new insights for the connection between internationalisation, trade credit and firm performance. Additionally, Finnish data provide an excellent environment for investigating trade credit usage because of the highly efficient nature of the Finnish payment system (Niskanen and Niskanen, 2006). During the research period, the share of electronic inter-company transactions ranged from $94 \%$ to $99.9 \%$ in Finland; this is the highest in Europe. According to the Finnish Bankers Association, the country average share of electronic payments is about $40 \%$ in Finland. Finnish data is also useful in terms of export trade because exports constitute about $40 \%$ of GDP, with little year-to-year variation. Second, we focus on SMEs while most studies on the connection of both trade receivables and internationalisation on firm performance have been conducted on large, listed firms. Third, we extend the literature on internationalisation and performance by introducing a new moderating variable: trade credit. Additionally, we extend the trade credit literature by differentiating between domestic and exporting firms.

The results suggest that the connection between trade receivables and performance is negative for domestic firms, yet positive for exporting firms, indicating that exporting firms benefit from longer payment periods. Additionally, our results confirm previous research on the connection between trade credit and internationalisation as opposed to firm performance in general.

This article proceeds by first reviewing relevant literature to illustrate the comprehensive nature of studies on this topic. The empirical part of this study shows how a firm's usage of trade credit is linked to performance and reveals the role of internationalisation in this connection. When considering the practical applicability of research in business management, the study reveals a demonstrable link between internationalisation and the financial success or performance of the firm. 


\section{Literature review and hypothesis development}

Previous studies show that trade credit levels vary greatly by country (Kneeshaw, 1995). For example, the average payment duration in B2B trade in 2019 was 23 days in Finland, 35 days in Switzerland, 61 days in Spain and 80 days in Greece (Intrum Justitia, 2019). When investigating the proportional shares of trade credit, Rajan and Zingales (1995) compared non-financial firms in the G7 countries. They found that the proportional share of accounts receivable varies from $13 \%$ (Canada) to $29 \%$ (Italy), whereas the variances in accounts payable range from $11.5 \%$ (Germany) to $17 \%$ (France). More recently, Mättö and Niskanen $(2019,2020)$ found substantial variation in the proportional share of trade credit by country in Europe. While the literature on accounting and finance provides several explanations for cross-country differences in corporate finance, only a few studies investigate the reasons behind the observed variations in trade credit. Demirgüç-Kunt and Maksimovic (2001) studied trade credit in 39 countries and found that a country's legal and financial systems predict its trade credit cycles. Furthermore, Mättö and Niskanen (2019) suggested that these observed variations can be partly explained by cultural dimensions and religion. They also found that some cross-country variations can be explained by variations in legal and financial systems between European countries.

\subsection{Trade credit extended and firm performance}

Most studies examining the connection between firm profitability and trade credit usage have used data on large, listed firms. For example, Shin and Soenen (1998), Deloof (2003) and Lazaridis and Tryfonidis (2006) were some of the first to investigate the relationship between working capital and firm profitability. Their results suggest a negative connection between firm performance and trade credit usage. More recently, Charitou et al. (2010), Raheman and Nasr (2007) and Nazir and Afza (2009) obtained similar results for Cypriot and Pakistani firms. Enqvist et al. (2014) investigated the relationship between working capital management and profitability in Finnish listed firms during different business cycles and found that the working capital cycle has a more significant negative impact on profitability (return on assets - ROA) during economic downturns than during normal or high business cycles. Contrary to most studies on the relationship between trade credit usage and firm performance, Box et al. (2018) found a statistically significant, positive relationship between accounts receivable and profitability. They found that companies with more trade credit reported significantly higher relative profitability ratios in terms of gross margins and ROA. In addition, companies that granted more trade credit were more likely to have higher turnover and market shares.

Typically, the bulk of the research on trade credit has focused on listed firms, as information on these firms is more easily available. Recently, trade credit research has also investigated this issue for SMEs in Spain, the UK, Mauritania, Belgium and Vietnam. Padachi (2006) used data on Mauritanian SMEs operating in manufacturing industries and observed a negative connection between days sales outstanding (DSO) and days payables outstanding (DPO) when regressed against ROA. García-Teruel and Martínez-Solano (2007) investigated the connection between working capital management and firm profitability in a sample of Spanish SMEs. The results of their study aligned with Padachi's (2006) study and suggested a negative connection between DSO and profitability. They also found a negative connection between the other 
measures of trade credit and profitability. Moreover, Kestens et al. (2012) investigated the connection between trade credit management and firm profitability during an economic downturn with a sample of Belgian SMEs. They found that corporate profitability declined because of the financial crisis; however, the impact on profitability was less severe for companies that had higher levels of accounts receivable in their balance sheets. Tran et al. (2017) used data on Vietnamese SMEs and observed a statistically significant and negative relationship between profitability and the cash conversion cycle, as well as its three components: DSO, days inventories outstanding (DIO) and DPO. Their results support earlier findings indicating that aggressive trade credit management can boost profitability.

Overall, previous studies established a connection between trade credit and firm performance in both SMEs and large firms. However, previous studies also suggest that the management of trade credit is more important in SMEs, probably because of restricted access to long-term funding (Petersen and Rajan, 1997). In addition, these studies suggest that the relative share of short-term assets and liabilities is higher in small firms than large firms (Baños-Caballero et al., 2010). Interestingly, Engemann et al. (2014) suggested that trade credit as a mechanism for resolving asymmetric information-related issues could be useful for firms attempting to penetrate the export market.

The common theme in studies on working capital and its various components is a negative relationship between trade receivable turnover and profitability. Based on this, we can conclude that profitability is likely to improve when the trade credit cycle is shortened. Combined, the results of empirical studies on the connection between profitability and trade credit suggest that an aggressive trade credit strategy is more likely to improve profitability than a passive strategy. This implies that the terms of payment should be structured so that payment times are shorter rather than longer. Given that these times can vary by country, however, such a task may prove difficult for firms operating in international markets. For example, it will be difficult to compete with a 30-day payment time when exporting to a country where 90-day payment cycles are typical.

\subsection{Internationalisation and firm performance}

In the seminal studies of internationalisation, Penrose (1959) focused on a firm's core competence and exploitation opportunities in foreign markets, while Johanson and Vahlne (1977) defined internationalisation as an incremental process whereby a firm expands its involvement in international markets. Later, Calof and Beamish (1995, p.116) defined internationalisation as "the process of adapting a firm's operations (strategy, structure, resource, etc.) to international environments." Griffith et al. (2008, p.1227) then underlined SME experiences in internationalisation as a primary theme to be explored through two research questions: 'What unique strategies do small and medium-sized firms employ in going international?" and "How successful are they?"

Traditional analyses of internationalisation suggest that the internationalisation process continues as long as performance projections are positive (Johanson and Vahlne, 2009). Lu and Beamish (2001) explain internationalisation as one of the most prominent paths for growth and reported that internationalisation at first yields higher performance. For small firms, especially those from developing countries, the domestic market is quite unstable, less attractive and less profitable than export markets (Reçica et al., 2019) and comprises a small market area (Gupta and Chauhan, 2020). In particular, firms seek to 
increase long-term profitability through internationalisation (i.e., growth) and find greater opportunities to achieve economies of scope and scale. Therefore, after the domestic market becomes saturated, business expansion in foreign markets is understood as appropriate to ensure growth and long-term survival. For small firms wishing to expand internationally, export is considered the most suitable mode of foreign market entry (Chen et al., 2016). At the same time, export markets are shown to be risky due to cultural differences and political and economic uncertainty (Rosado-Serrano et al., 2018).

Several researchers have found that higher levels of internationalisation lead to better performance (e.g., Daniels and Bracker, 1989; Zahra et al., 2000) while some have failed to show any relationship (Buckley et al., 1978) and others have even found a negative relationship (Kumar, 1984; Michel and Shaked, 1986). Alternatively, some studies have shown nonlinear relationships, such as a U-shaped (Contractor et al., 2007; Lu and Beamish, 2001; Ruigrok and Wagner, 2003), an inverted U-shaped (Daniels and Bracker, 1989; Hitt et al., 1997), or an S-shaped relationship (Contractor et al., 2007; Lu and Beamish, 2001; Thomas and Eden, 2004). For instance, Thomas and Eden (2004) reported a three-point sigmoid relationship between internationalisation and performance, or an S-curve. Using a sample of international new ventures exploring the early stages of internationalisation within newly born and small firms, Almodóvar and Rugman (2014) found a traditional M-shaped and W-shaped relationship between internationalisation and performance, which explained the global M-curve. Despite numerous findings in empirical research, however, the relationship between a firm's internationalisation and performance remains one of the major unresolved research questions in the international business field (Powell, 2014).

Table 1 The main definitions of the study and the research gap

\begin{tabular}{|c|c|c|}
\hline Key concepts & Definitions & Research gap \\
\hline Trade credit & $\begin{array}{l}\text { Trade credit is defined as a } \\
\text { business-to-business (B2B) agreement } \\
\text { in which customers can purchase goods } \\
\text { on account with delayed cash payments } \\
\text { (Niskanen and Niskanen, 2006). }\end{array}$ & \multirow{3}{*}{$\begin{array}{l}\text { The relationship between a } \\
\text { firm's internationalisation and } \\
\text { performance remains an } \\
\text { unresolved research question } \\
\text { in the international business } \\
\text { field. Moreover, there is lack } \\
\text { of investigation into the } \\
\text { relationship between trade } \\
\text { credit and a firm's } \\
\text { performance in connection } \\
\text { with internationalisation in } \\
\text { general and export activities at } \\
\text { the firm level. }\end{array}$} \\
\hline Performance & $\begin{array}{l}\text { Performance is a multidimensional } \\
\text { concept that defines the success of a } \\
\text { business as well as its ability to achieve } \\
\text { business objectives. Traditionally firms } \\
\text { can measure performance based on } \\
\text { annual sales and firm size (Civelek } \\
\text { et al., 2015). }\end{array}$ & \\
\hline Internationalisation & $\begin{array}{l}\text { Internationalisation is an incremental } \\
\text { process whereby a firm expands its } \\
\text { involvement in international markets } \\
\text { (Johanson and Vahlne, 1977). Calof } \\
\text { and Beamish (1995, p.116) enlarged } \\
\text { internationalisation as "the process of } \\
\text { adapting a firm's operations (strategy, } \\
\text { structure, resource, etc.) to international } \\
\text { environments." }\end{array}$ & \\
\hline
\end{tabular}




\subsection{Conclusions}

Based on the earlier studies above, it can be assumed that there is a connection between internationalisation, trade credit usage and firm performance in terms of both growth and profitability. Therefore, Table 1 summarises the main concepts of the study and the research gap discussed above.

\subsection{Hypothesis development}

Numerous studies have investigated the relationship between trade credit usage and firm performance (e.g., Deloof, 2003; García-Teruel and Martínez-Solano, 2007). While the results of previous studies are somewhat mixed, the bulk of this literature suggests a negative connection. Based on this, we hypothesise the following:

H1 There is a negative connection between the use of trade credit and firm performance.

Previous researchers have made significant efforts to not only explain the relationship between internationalisation and firm performance, but also to prove it as either positive or negative. For example, Zahra et al. (2000) suggested that there is a positive relationship, while others, such as Michel and Shaked (1986), indicated the opposite. So far, an exhaustive explanation has not been identified, and the relationship seems to be dependent on a multitude of factors (Sullivan, 1994; Thomas and Eden, 2004). Based on previous research, we posit that the relationship between internationalisation and firm performance can be either positive or negative. For this reason, we hypothesise the following:

$\mathrm{H} 2 \mathrm{a}$ There is a positive connection between firm performance and the degree of internationalisation.

$\mathrm{H} 2 \mathrm{~b}$ There is a negative connection between firm performance and the degree of internationalisation.

Figure 1 The three hypotheses linking trade credit, degree of internationalisation and firm performance (see online version for colours)

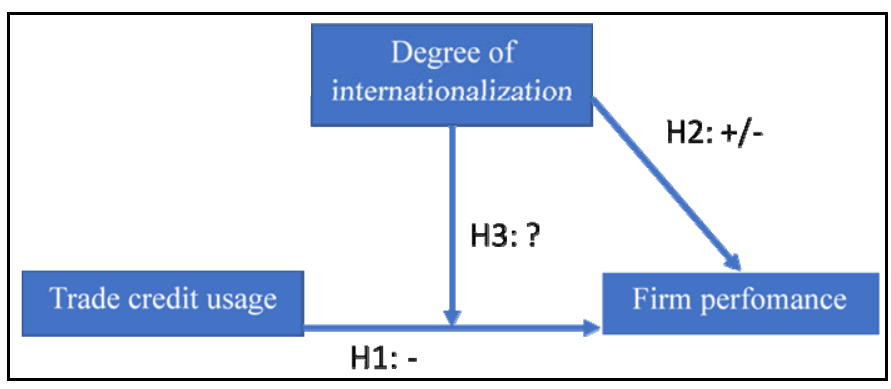

While there is little evidence on how internationalisation affects the connection between profitability and trade credit in previous literature, Engemann et al. (2014) suggested that the uncertainty derived from information asymmetry is a problem, especially in international trade. They also suggested that trade credit can be used to alleviate this uncertainty. Previous studies also observed that the terms of trade, and the relative 
amount of extended trade credit, differ greatly by country (e.g., Mättö and Niskanen, 2019). Based on this, we hypothesise that:

H3 Internationalisation affects the connection between profitability and trade credit usage.

Figure 1 presents the three hypotheses investigated in this study. Figure 1 demonstrates the linkages between trade credit, internationalisation and firm performance as well as their expected signs.

\section{Data and methodology}

Our data is from a survey carried out in two rounds in four Eastern Finland (Northern Savo, Southern Savo, North Carelia and Kainuu) in 2007 and 2012. The questionnaires were sent to the chief executive officers with the following criteria:

1 at least two employees

2 legal form is primarily limited liability

3 all industries represented, excluding primary production.

This data offers a unique set of variables, including information on the export activities of the sample firms. The data covers the years 2001-2011, and is complemented with financial data from the Voitto+ database provided by Suomen Asiakastieto Oy. Industry codes are taken from the Amadeus database. Of the targeted small and medium-sized firms, answers were received from a total of 770 firms in Eastern Finland. The initial number of firm-year observations was 9,480; however, the number of observations used in the analysis is smaller due to missing data on some variables. The number of firm-year observations in the regression models varies between 3,832 and 3,910. To take into account the possibility of a response-bias, we have also performed non-respondent tests for the database. The tests suggest that the firms that responded to the survey are statistically significantly similar to the whole sample. We also consider the possibility of a common method bias and apply Harman's single-factor test. We load all variables into a principal component factor analysis and examine a rotated factor solution. None of the factors account for over $18.1 \%$ of the total variance.

Table 2 presents all the variables used in the empirical part of the study. In line with several previous studies on the connection between both internationalisation and performance, as well as trade credit usage and performance, we use ROA (which is defined as the percentage of net income after tax to total assets) as the dependent variable in this study. The same measure for firm performance has been used by Hitt et al. (1997), Lu and Beamish (2001) and Thomas and Eden (2004) in previous studies on internationalisation. At the same time, ROA has also been found to be a good measure of performance in trade credit research (e.g., Enqvist et al., 2014). In a robustness check, we use an additional measure (ebit) for profitability. Our hypothesis variables are recturn (days receivables outstanding), doi (degree of export sales to total sales), and doi2 (square of doi) to capture possible nonlinear associations.

While trade credit entails both accounts payable and accounts receivable, we use accounts receivable as our measure for trade credit in this study as our measure of internationalisation is derived from the firms' export activities. We select days 
receivables outstanding because it is the best measure available in financial statements to describe payment terms. This has been previously used in the association between trade credit and profitability by Deloof (2003) and García-Teruel and Martínez-Solano (2007). Our measure of internationalisation is doi, the degree of internationalisation measured by the degree of export sales to total sales. As defined by Sullivan (1994), foreign sales to total sales (FSTS) define the international performance of a firm although alternative variables to measure internationalisation could be, for instance, the international exposure of top management (Agnihotri and Bhattacharya, 2015). Additionally, we use the degree of internationalisation squared, as several studies suggest that the relationship between internationalisation and firm performance is nonlinear (e.g., Lu and Beamish, 2001).

Table 2 Variable definitions

\begin{tabular}{lcc}
\hline Name & Definition & Formula \\
\hline ROA & Return of assets (\%) & (Net income after tax / total assets) $* 100 \%$ \\
ebit & Earnings before interest and tax (\%) & (ebit / sales) $* 100 \%$ \\
doi & Degree of internationalisation (\%) & Share of export sales \\
Ddoi & Dummy for international firm & $1=$ export sales, 0 otherwise \\
recturn & Receivable days & Accounts receivable / sales $* 365$ \\
lnsize & Natural logarithm of total assets & Ln(total assets) \\
growth & Change of sales & (Salest - salest -1$) /$ salest -1 \\
lnage & Logarithm of firm age & ln(age +1$)$ \\
rd_intensity & Research and development intensity & Intangible assets / total assets \\
Year & Fiscal year & \\
\hline
\end{tabular}

In addition to our main variables, we also control for known factors associated with firm profitability. Specifically, we control firm size (lnsize) by the natural logarithm of total assets, change of sales (growth), firm age (lnage) and research and development intensity (rd_intensity). Variable definitions are presented in Table 2.

Table 3 Descriptive statistics

\begin{tabular}{lccccc}
\hline & $N$ & Mean & St.dev. & Min. & Max. \\
\hline ROA & 3,910 & 15.547 & 15.116 & -24 & 60.9 \\
ebit & 3,910 & 8.273 & 15.807 & -422 & 69.4 \\
doi & 3,910 & .06 & .175 & 0 & 1 \\
Ddoi & 3,910 & .257 & .437 & 0 & 1 \\
recturn & 3,910 & 32.9 & 96.068 & 0 & 4,137 \\
lnsize & 3,910 & 6.132 & 1.264 & 3.434 & 9.817 \\
growth & 3,910 & .182 & 2.081 & -.99 & 99.999 \\
lnage & 3,910 & 2.602 & .751 & 0 & 4.635 \\
rd_intensity & 3,910 & .018 & .059 & 0 & .815 \\
year & 3,910 & & & 2,000 & 2,011 \\
\hline
\end{tabular}

Note: Variable definitions are shown in Table 2. 
Table 4 Correlation matrix $\mathrm{n}=3,910$

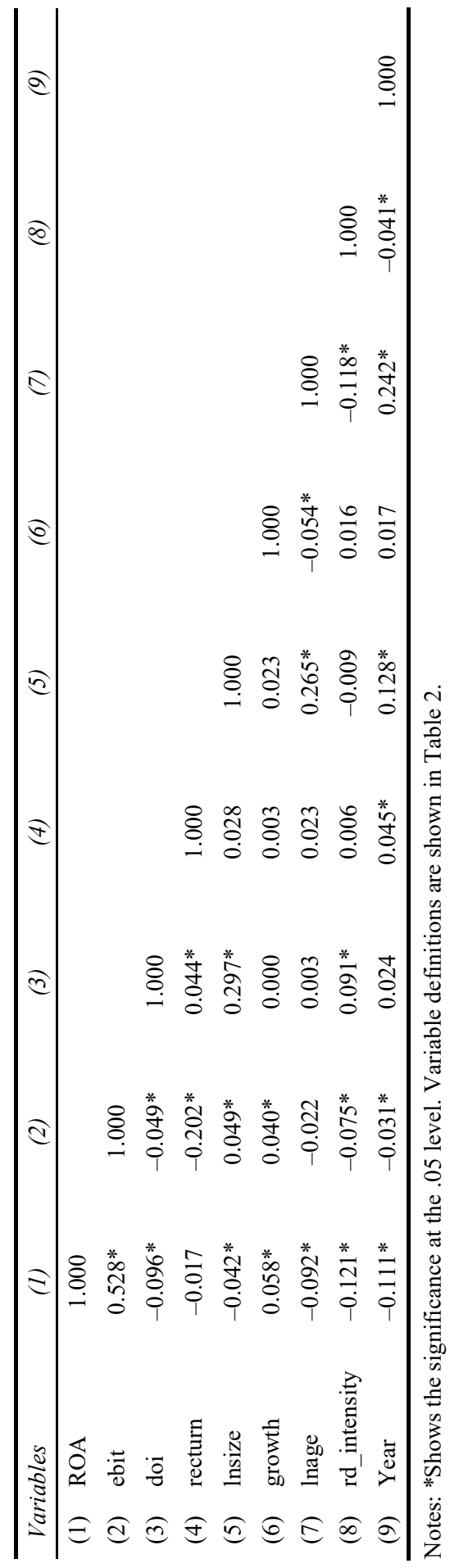


Table 3 presents the descriptive statistics. On average, the profitability of firms in our sample is about $15.5 \%$ using ROA and about $8.3 \%$ using ebit. Additionally, about $26 \%$ of our sample firms have export sales. The average share of international sales is about $6 \%$, while the average number of DSO is about 33 days.

We test our hypothesis with a linear regression model with industry and year fixed effects because of the panel nature of our dataset. Panel data methods have been used in trade credit studies for controlling unobservable heterogeneity and endogeneity (Bastos and Pindado, 2013). We use year and industry fixed effects and heteroscedasticity corrected standard errors for coefficient estimates. To examine the possible existence of multicollinearity, we run Pearson correlations (Table 4). We also run a t-test for comparing exporting and non-exporting firms. The t-test is used for comparing continuous variable means between groups, which in this case are exporting firms and non-exporting firms. Our regression model is as follows:

$$
\operatorname{roa}_{i, t}=\beta_{0}+\beta_{1} \text { recturn }_{i, t}+\beta_{3} \text { doi }_{i, t}^{2}+\text { controls }+\varepsilon
$$

\section{Empirical results}

We first run t-tests to get an idea about the association between internationalisation and firm profitability and managing receivables (Table 5). We find that exporting firms are less profitable in terms of both ROA and ebit. In terms of ROA, exporting firms have a return of assets of $13.2 \%$, while ROA for non-internationalised firms is $16.3 \%$. The difference is statistically significant, with a t-value of 5.65. The corresponding figures for ebit are $8.8 \%(8.0)$ for internationalised (non-internationalised) firms $(t=2.35)$. The collection period of receivables is about five days longer for internationalised firms: about 36 days. The difference, however, is not statistically significant.

Table 5 T-test for ROA, ebit and recturn by internationalisation dummy

\begin{tabular}{lcccccccc}
\hline Int.dummy & Obs $(0)$ & Obs(1) & Mean $(0)$ & Mean(1) & dif & St_err & t_value & p_value \\
\hline ROA & 2,907 & 1,003 & 16.344 & 13.236 & 3.108 & .551 & 5.65 & .000 \\
ebit & 2,850 & 982 & 8.669 & 7.128 & 1.452 & .579 & 2.35 & .007 \\
recturn & 2,907 & 1,003 & 31.757 & 36.214 & -4.457 & 3.518 & -1.25 & .205 \\
\hline
\end{tabular}

Notes: Number of observations, means, standard errors, $t$ and p-statistics. Variable definitions are shown in Table 2.

We turn next to our regression models (Table 6). First, the receivables collection period (recturn) takes a statistically significant and negative coefficient in column 6 , suggesting that firms with longer collection periods are less profitable. While the results for this variable are not statistically significant in the other models, this result partly supports Hypothesis $\mathrm{H} 1$ and is in line with most existing studies. From a practical point of view, this can be seen as a result of the Finnish business environment, which has an established payment behaviour of relatively short payment times in B2B trade.

The coefficient for doi is negative and statistically significant. This is in line with Hypothesis $\mathrm{H} 2 \mathrm{~b}$, which shows a negative relationship between internationalisation and performance. This result corresponds with Michel and Shaked (1986), who investigated US multinationals and found that domestically operating firms outperform internationally 
oriented firms. Depending on the model, the coefficient varies from about 6 to 19 , indicating that, at the highest, a one percentage point increase in export sales share decreases ROA by 0.19 percentage points.

Table 6 Regression results, OLS dependent variable ROA with year and industry fixed effects, regression coefficients and standard errors

\begin{tabular}{|c|c|c|c|c|c|c|}
\hline & (1) & (2) & (3) & (4) & (5) & (6) \\
\hline & $R O A$ & $R O A$ & $R O A$ & $R O A$ & $R O A$ & $R O A$ \\
\hline \multirow[t]{2}{*}{ recturn } & -0.002 & & & -0.001 & -0.001 & $-0.002 *$ \\
\hline & $(0.002)$ & & & $(0.002)$ & $(0.002)$ & $(0.001)$ \\
\hline \multirow[t]{2}{*}{ doi } & & $-6.150^{*}$ & $-19.065^{* *}$ & $-6.115^{*}$ & $-18.995 * *$ & $-11.395^{* * *}$ \\
\hline & & (3.146) & $(7.735)$ & $(3.150)$ & (7.739) & (3.638) \\
\hline \multirow[t]{2}{*}{ doi2 } & & & 16.395 & & 16.347 & \\
\hline & & & (11.331) & & (11.341) & \\
\hline \multirow[t]{2}{*}{ doi $\times$ recturn } & & & & & & $0.111^{*}$ \\
\hline & & & & & & $(0.065)$ \\
\hline \multirow[t]{2}{*}{ lnsize } & 0.405 & $0.633^{*}$ & $0.703^{*}$ & $0.633^{*}$ & $0.703^{*}$ & $0.614 *$ \\
\hline & $(0.368)$ & $(0.360)$ & $(0.372)$ & $(0.360)$ & $(0.372)$ & $(0.358)$ \\
\hline \multirow[t]{2}{*}{ growth } & $0.396^{* * *}$ & $0.388 * * *$ & $0.384 * * *$ & $0.388 * * *$ & $0.385^{* * *}$ & $0.389 * * *$ \\
\hline & $(0.142)$ & $(0.143)$ & $(0.144)$ & $(0.143)$ & $(0.144)$ & $(0.143)$ \\
\hline \multirow[t]{2}{*}{ lnage } & $-1.715^{* * *}$ & $-1.796 * * *$ & $-1.741 * * *$ & $-1.794 * * *$ & $-1.739 * * *$ & $-1.810 * * *$ \\
\hline & $(0.596)$ & $(0.589)$ & $(0.589)$ & $(0.589)$ & $(0.589)$ & $(0.587)$ \\
\hline \multirow[t]{2}{*}{ rd_intensity } & $-35.969 * * *$ & $-34.707 * * *$ & $-34.539 * * *$ & $-34.699 * * *$ & $-34.532 * * *$ & $-35.301 * * *$ \\
\hline & $(5.035)$ & $(5.027)$ & $(5.145)$ & $(5.028)$ & $(5.145)$ & $(5.084)$ \\
\hline \multirow[t]{2}{*}{ _cons } & $15.840 * * *$ & $14.454 * * *$ & $13.922 * * *$ & $14.509^{* * *}$ & $13.974 * * *$ & $14.681 * * *$ \\
\hline & $(3.160)$ & $(3.182)$ & $(3.240)$ & $(3.187)$ & $(3.245)$ & $(3.174)$ \\
\hline $\begin{array}{l}\text { Year fixed } \\
\text { effects }\end{array}$ & Yes & Yes & Yes & Yes & Yes & Yes \\
\hline $\begin{array}{l}\text { Industry fixed } \\
\text { effects }\end{array}$ & Yes & Yes & Yes & Yes & Yes & Yes \\
\hline Obs. & 3,910 & 3,910 & 3,910 & 3,910 & 3,910 & 3,910 \\
\hline R-squared & 0.079 & 0.083 & 0.085 & 0.083 & 0.085 & 0.085 \\
\hline
\end{tabular}

Notes: Standard errors are shown in parentheses. Variable definitions are shown in Table 2.

$* * * p<0.01, * * p<0.05$ and $* p<0.1$.

To investigate the potential nonlinear association between export sales and firm performance, we add a second-degree term of the international sales doi2 to the model. The coefficient for doi2 is not statistically significant, indicating that the relationship between internationalisation and profitability is linear rather than nonlinear. This contradicts many recent studies, e.g., Olmos and Díez-Vial (2015), which found a W-shaped relationship for Spanish firms. The positive sign of this variable would have indicated a U-shape relationship. The model in column 6 includes a vnew variable, which captures the interaction effect for international sales and a receivable collection period. In this model, both the interactive term and recturn have a statistically significant coefficient 
at a $90 \%$ level. This result confirms Hypothesis H3, which shows that the relationship between trade credit granted and profitability depends on the degree of internationalisation. The lower the share of export sales, the more the collection period has a negative influence on profitability. On average, one additional day in sales outstanding decreases the negative internationalisation effect on ROA by 0.11 percentage points. Also, the longer the collection period, the greater the positive influence of international sales on profitability. Firms with a larger share of sales from abroad might benefit from longer collection periods. This result can confirm the findings of Engemann et al. (2014), which suggested that trade credit can be used to alleviate information asymmetry related problems in international trade, thereby enhancing firm performance.

Table 7 Regression results, OLS dependent variable ebit with year and industry fixed effects, regression coefficients and standard errors

\begin{tabular}{|c|c|c|c|c|c|c|}
\hline & (1) & (2) & (3) & (4) & (5) & (6) \\
\hline & ebit & ebit & ebit & ebit & ebit & ebit \\
\hline \multirow[t]{2}{*}{ recturn } & $0.009 * *$ & & & $0.009^{*}$ & $0.009 *$ & $0.008^{* *}$ \\
\hline & $(0.004)$ & & & $(0.005)$ & $(0.005)$ & $(0.004)$ \\
\hline \multirow[t]{2}{*}{ doi } & & -3.203 & -8.083 & -3.419 & -8.525 & $-7.901 * * *$ \\
\hline & & $(2.345)$ & (5.924) & $(2.316)$ & $(5.921)$ & $(2.382)$ \\
\hline \multirow[t]{2}{*}{ doi2 } & & & 6.225 & & 6.511 & \\
\hline & & & (8.423) & & $(8.380)$ & \\
\hline \multirow[t]{2}{*}{ doi $\times$ recturn } & & & & & & $0.096 * *$ \\
\hline & & & & & & $(0.046)$ \\
\hline \multirow[t]{2}{*}{ lnsize } & $1.192 * * *$ & $1.336 * * *$ & $1.363 * * *$ & $1.320 * * *$ & $1.349 * * *$ & $1.300 * * *$ \\
\hline & $(0.261)$ & $(0.259)$ & $(0.268)$ & $(0.258)$ & $(0.267)$ & $(0.256)$ \\
\hline \multirow[t]{2}{*}{ growth } & $0.199 * * *$ & $0.198 * * *$ & $0.197 * * *$ & $0.195 * * *$ & $0.194 * * *$ & $0.196 * * *$ \\
\hline & $(0.049)$ & $(0.049)$ & $(0.048)$ & $(0.049)$ & $(0.049)$ & $(0.050)$ \\
\hline \multirow[t]{2}{*}{ lnage } & 0.049 & 0.011 & 0.032 & 0.007 & 0.029 & -0.002 \\
\hline & $(0.399)$ & $(0.399)$ & $(0.399)$ & $(0.397)$ & $(0.397)$ & $(0.395)$ \\
\hline \multirow[t]{2}{*}{ rd_intensity } & $-18.311 * * *$ & $-17.739 * * *$ & $-17.641 * * *$ & $-17.790 * * *$ & $-17.687 * * *$ & $-18.248^{* * *}$ \\
\hline & (3.509) & (3.480) & (3.439) & (3.482) & $(3.441)$ & $(3.522)$ \\
\hline \multirow[t]{2}{*}{ _cons } & 3.153 & 2.570 & 2.359 & 2.402 & 2.179 & 2.558 \\
\hline & $(2.418)$ & $(2.456)$ & (2.495) & $(2.446)$ & $(2.485)$ & $(2.438)$ \\
\hline Obs. & 3,832 & 3,832 & 3,832 & 3,832 & 3,832 & 3,832 \\
\hline $\begin{array}{l}\text { Year fixed } \\
\text { effects }\end{array}$ & Yes & Yes & Yes & Yes & Yes & Yes \\
\hline $\begin{array}{l}\text { Industry } \\
\text { fixed effects }\end{array}$ & Yes & Yes & Yes & Yes & Yes & Yes \\
\hline R-squared & 0.081 & 0.079 & 0.080 & 0.085 & 0.086 & 0.089 \\
\hline
\end{tabular}

Notes: Standard errors are shown in parentheses. Variable definitions are shown in Table 2.

$* * * p<0.01, * * p<0.05$ and $* p<0.1$. 


\subsection{Robustness check}

To take into account the fact that our sample contains private firms, we also use an alternative measure for profitability. While ROA is often used, it incorporates more from an investor's perspective. Ebit, on the other hand, measures the effectiveness of a business's functions and is not sensitive to investment or dividend policy. Table 7 presents the results for the same models seen in Table 6 but with ebit as a dependent variable. The results are similar to earlier results, with the exception that recturn shows significant or almost significant positive signs in every model. This means that, in terms of ebit, a longer collection period improves profitability. However, the economic influence is relatively small. Again, international sales, together with a longer collection period, result in improved firm profitability. This strengthens our main findings on the connection between trade credit usage, internationalisation and firm performance. We also run our analysis without potential outliers. We deleted $1 \%$ and $99 \%$ level observations from each of our hypothesis variables as possible outliers, and our un-tabulated results remain the same.

\section{Conclusions}

This study investigates whether a connection exists between extending trade credit and firm performance and whether this association depends on the degree of internationalisation. To answer these questions, we use survey data from Finnish SMEs. Previous literature suggests a negative connection between both trade receivables and internationalisation as opposed to firm performance. However, there is little evidence on the interplay between trade receivables and internationalisation in connection with firm performance.

Our results include two major findings. First, a linear relationship exists between the degree of internationalisation and firm performance. A negative relationship states that increasing export sales does not necessarily result in improved profitability. In fact, our results suggest just the opposite, which confirms the results of many previous studies such as Michel and Shaked (1986). Second, while domestic firms have a negative relationship between trade receivables and profitability (see, e.g., Charitou et al., 2010; Deloof, 2003; Lazaridis and Tryfonidis, 2006; Nazir and Afza, 2009), our findings indicate that exporting firms benefit from longer collection periods. More precisely, our findings indicate that each additional day in receivables decreases the negative effect of internationalisation on performance. This finding extends the previous literature by introducing a new variable, which affects the connection between internationalisation and firm performance. Furthermore, this finding contributes to the trade credit literature by showing that the previously observed (mostly) negative connection between trade receivables and firm performance is influenced by firm internationalisation and is not necessarily accurate for all types of firms.

Our results have several scientific and practical implications. Scientifically, our findings, which offer a new variable, trade receivables, to the internationalisation-performance construct, suggest that there may be other important factors affecting this relationship that have not been previously investigated. This warrants for more research on how internationalisation is connected with firm performance in different types of firms such as born globals, younger firms as opposed to 
older firms, SMEs, multinationals, etc. This also calls for more research on how the internationalisation-performance construct is affected by different choices at the firm level, such as leverage, liquidity or asset structure. The findings also suggest that the connection between trade credit and firm performance is not as straightforward as suggested in previous literature. Instead, it is possible that this connection varies between different types of firms. This calls for more research across countries, firm types and cultures. For business practitioners, our results imply that it is not necessarily beneficial to avoid longer payment periods, especially in international trade. Surprisingly, longer payment periods can result in improved firm performance. Therefore, managers should not turn away from export markets that require longer payment periods. Instead, these markets seem to offer possibilities for increased profits.

This study has some limitations. The main limitation is that we only have data from one country, Finland, which is a small open economy that is relatively dependent on export trade. Additionally, Finnish firms are known to use very short payment periods in comparison to other European countries. It is possible that the results would be different if the data were from a country with longer payment periods. Due to this, the results open new avenues for research in different countries and cultural environments. For example, Mättö and Niskanen (2019) found that Hofstede's (2011) and Schwartz's (1992, 1997) cultural dimensions explain cross-country variation in trade credit. Also, Budeva and Mullen (2016) find that cultural differences between the home country and target country have a significant effect on export activities. It would be interesting to investigate how this is reflected in exporting firms as opposed to domestic firms. Moreover, the cultural differences between the exporting country and the target market may plausibly impact the results. Based on Arvidsson et al. (2020), Arvidsson and Coudounaris (2020) and our own findings, we recommend future researchers investigate the internationalisation process of new firms with a focus on trade credit usage and performance. To gain a more in-depth understanding of the reasons behind the current results, qualitative research methods might be useful.

\section{References}

Agnihotri, A. and Bhattacharya, S. (2015) 'Determinants of export intensity in emerging markets: an upper echelon perspective', Journal of World Business, Vol. 50, No. 4, pp.687-695.

Akerlof, G.A. (1970) 'The market for lemons', Quality Uncertainty and the Market Mechanism, Vol. 84, No. 3, pp.488-500.

Almodóvar, P. and Rugman, A.M. (2014) 'The MCurve and the performance of Spanish international new ventures', British Journal of Management, Vol. 25, pp.S6-S23.

Arvidsson, H.G. and Coudounaris, D.N. (2020) 'Effectuation versus causation: a case study of an IT recruitment firm', International Journal of Entrepreneurship, Vol. 24, No. 4, pp.1-13.

Arvidsson, H.G., Coudounaris, D.N. and Arvidsson, R. (2020) 'The shift from causation to effectuation for international entrepreneurs: attitudes and attitude change versus social representations', International Journal of Entrepreneurship, Vol. 24, No. 3, pp.1-23.

Baños-Caballero, S., García-Teruel, P.J. and Martínez-Solano, P. (2010) 'Working capital management in SMEs', Accounting and Finance, Vol. 50, No. 3, pp.511-527.

Bastos, R. and Pindado, J. (2013) 'Trade credit during a financial crisis: a panel data analysis', Journal of Business Research, Vol. 66, No. 5, pp.614-620.

Box, T., Davis, R., Hill, M. and Lawrey, C. (2018) 'Operating performance and aggressive trade credit policies’, Journal of Banking and Finance, April, Vol. 89, pp.192-208. 
Brache, J. and Felzensztein, C. (2019) 'Geographical co-location on Chilean SME's export performance', Journal of Business Research, December, Vol. 105, pp.310-321.

Buckley, P.J., Dunning, J.H. and Pearce, R.D. (1978) 'The influence of firm size, industry, nationality, and degree of multinationality on the growth and profitability of the world's largest firms, 1962-1972', Review of World Economics, Vol. 114, No. 2, pp.243-257.

Budeva, D. and Mullen, M.R. (2016) 'Does culture matter for international market selection?', International Journal of Export Marketing, Vol. 1, No. 2, pp.193-214.

Calof, J.L. and Beamish, P.W. (1995) 'Adapting to foreign markets: explaining internationalization', International Business Review, Vol. 4, No. 2, pp.115-131.

Charitou, M.S., Elfani, M. and Lois, P. (2010) 'The effect of working capital management on firms profitability: empirical evidence from an emerging market', Journal of Business and Economics Research, Vol. 8, No. 12, pp.63-68.

Chen, J., Sousa, C. and He, X. (2016) 'The determinants of export performance: a review of the literature 2006-2014', International Marketing Review, Vol. 33, No. 5, pp.626-670.

Civelek, M.E., Çemberci, M., Artar, O. and Uca, N. (2015) Key Factors of Sustainable Firm Performance: A Strategic Approach, Zea Books, Lincoln, Nebraska.

Contractor, F.J., Kumar, V. and Kundu, S.K. (2007) 'Nature of the relationship between international expansion and performance: the case of emerging market firms', Journal of World Business, Vol. 42, No. 4, pp.401-417.

Daniels, J.D. and Bracker, J. (1989) 'Profit performance: do foreign operations make a difference?', Management International Review, Vol. 29, No. 1, pp.46-57.

De Noni, I. and Apa, R. (2015) 'The moderating effect of exploitative and exploratory learning on internationalisation-performance relationship in SMEs', Journal of International Entrepreneurship, Vol. 13, No. 2, pp.96-117.

Deloof, M. (2003) 'Does working capital management affect profitability of Belgian firms?', Journal of Business Finance and Accounting, Vol. 30, Nos. 3-4, pp.573-588.

Demirgüç-Kunt, A. and Maksimovic, V. (2001) Firms as Financial Intermediaries: Evidence from Trade Credit Data, pp.26-96, Development Research Group, World Bank, SSRN: 632764.

Engemann, M., Eck, K. and Schnitzer, M. (2014) 'Trade credits and bank credits in international trade: substitutes or complements?', The World Economy, Vol. 37, No. 11, pp.1507-1540.

Enqvist, J., Graham, M. and Nikkinen, J. (2014) 'The impact of working capital management on firm profitability in different business cycles: evidence from Finland', Research in International Business and Finance, August, Vol. 32, pp.36-49.

García-Teruel, P.J. and Martínez-Solano, P. (2007) 'Effects of working capital management on SME profitability', International Journal of Managerial Finance, Vol. 3, No. 2, pp.164-177.

Griffith, D.A., Cavusgil, S.T. and Xu, S. (2008) 'Emerging themes in international business research', Journal of International Business Studies, Vol. 39, No. 7, pp.1220-1235.

Gupta, P. and Chauhan, S. (2020) 'Firm capabilities and export performance of small firms: a meta-analytical review', European Management Journal, Vol. 39, No. 5, pp.1-19.

Hitt, M.A., Hoskisson, R.E. and Kim, H. (1997) 'International diversification: effects on innovation and firm performance in product-diversified firms', Academy of Management Journal, Vol. 40, No. 4, pp.767-798.

Hofstede, G. (2011) 'Dimensionalizing cultures: the Hofstede model in context', Online Readings in Psychology and Culture, Vol. 2, No. 1, p.2307-0919.

Intrum Justitia (2019) European Payment Report 2018 [online] https://www.intrum.fi/media (accessed 3 March 2020).

Johanson, J. and Vahlne, J.E. (1977) 'The internationalization process of the firm - a model of knowledge development and increasing foreign market commitments', Journal of International Business Studies, Vol. 8, No. 1, pp.23-32. 
Johanson, J. and Vahlne, J.E. (2009) 'The Uppsala internationalization process model revisited: from liability of foreignness to liability of outsidership', Journal of International Business Studies, Vol. 40, No. 9, pp.1411-1431.

Kestens, K., Van Cauwenberge, P. and Bauwhede, H.V. (2012) 'Trade credit and company performance during the 2008 financial crisis', Accounting \& Finance, Vol. 52, No. 4, pp.1125-1151.

Kneeshaw, J.T.A. (1995) Survey of Non-Functional Sector Balance Sheets in Industrialised Countries: Implications for the Monetary Policy Transmission Mechanism, BIS Working Paper, No. 25, April, SSRN: https://ssrn.com/abstract=868428.

Kuivalainen, O. and Sundqvist, S. (2007) 'Profitability of rapid internationalization: the relationship between internationalization intensity and firms' export performance', Journal of Euromarketing, Vol. 16, Nos. 1-2, pp.59-69.

Kumar, M.S. (1984) Growth, Acquisition and Investment: An Analysis of the Growth of Industrial Firms and Their Overseas Activities, Cambridge University Press, Cambridge.

Lazaridis, I. and Tryfonidis, D. (2006) 'Relationship between working capital management and profitability of listed companies in the Athens Stock Exchange', Journal of Financial Management and Analysis, Vol. 19, No. 1, pp.26-35.

Lu, J. and Beamish, P. (2001) 'The internationalization and performance of SMEs', Strategic Management Journal, Vol. 22, Nos. 6-7, pp.565-586.

Mättö, M. and Niskanen, M. (2019) 'Religion, national culture and cross-country differences in the use of trade credit', International Journal of Managerial Finance, Vol. 15, No. 3, pp.350-370.

Mättö, M. and Niskanen, M. (2020) 'Role of the legal and financial environments in determining the efficiency of working capital management in European SMEs', International Journal of Finance \& Economics, early view [online] https://doi.org/10.1002/ijfe.2061 (accessed 27 August 2021).

Michel, A. and Shaked, I. (1986) 'Multinational corporations vs. domestic corporations: financial performance and characteristics', Journal of International Business Studies, Vol. 17, No. 3, pp.89-100.

Nazir, M.S. and Afza, T. (2009) 'Impact of aggressive working capital management policy on firms' profitability', IUP Journal of Applied Finance, Vol. 15, No. 8, pp.19-30.

Niskanen, J. and Niskanen, M. (2006) 'The determinants of corporate trade credit policies in a bank-dominated financial environment: the case of Finnish small firms', European Financial Management, Vol. 12, No. 1, pp.81-102.

Olmos, M.F. and Díez-Vial, I. (2015) 'Internationalization pathways and the performance of SMEs', European Journal of Marketing, Vol. 49, Nos. 3/4, pp.420-443.

Padachi, K. (2006) 'Trends in working capital management and its impact on firms' performance: an analysis of Mauritian small manufacturing firms', International Review of Business Research Papers, Vol. 2, No. 2, pp.45-58.

Pangarkar, N. (2008) 'Internationalization and performance of small-and medium-sized enterprises', Journal of World Business, Vol. 43, No. 4, pp.475-485.

Penrose, R. (1959) 'The apparent shape of a relativistically moving sphere', in Mathematical Proceedings of the Cambridge Philosophical Society, Cambridge University Press, Cambridge, pp.137-139.

Petersen, M.A. and Rajan, R.G. (1997) 'Trade credit: theories and evidence', Review of Financial Studies, Vol. 10, No. 3, pp.661-691.

Powell, K.S. (2014) 'From M-P to MA-P: multinationality alignment and performance', Journal of International Business Studies, Vol. 45, No. 2, pp.211-226.

Raheman, A. and Nasr, M. (2007) 'Working capital management and profitability - case of Pakistani firms', International Review of Business Research Papers, Vol. 3, No. 1, pp.279-300.

Rajan, R. and Zingales, L. (1995) 'What do we know about capital structure? Some evidence from international data', The Journal of Finance, Vol. 50, No. 5, pp.1421-1460. 
Reçica, F., Hashi, I., Jackson, I. and Krasniqi, B.A. (2019) 'Innovation and the export performance of firms in transition economies: the relevance of the business environment and the stage of transition', International Journal of Entrepreneurship and Small Business, Vol. 38, No. 4, pp.476-506.

Rosado-Serrano, A., Paul, J. and Dikova, D. (2018) 'International franchising: a literature review and research agenda', Journal of Business Research, April, Vol. 85, pp.238-257.

Ruigrok, W. and Wagner, H. (2003) 'Internationalization and performance: an organizational learning perspective', MIR: Management International Review, Vol. 43, No. 1, pp.63-83.

Ruigrok, W., Amann, W. and Wagner, H. (2007) 'The internationalization-performance relationship at Swiss firms: a test of the S-shape and extreme degrees of internationalization', Management International Review, Vol. 47, No. 3, pp.349-368.

Schwartz, S.H. (1992) 'Universals in the content and structure of values: theoretical advances and empirical tests in 20 countries', in Advances in Experimental Social Psychology, Vol. 25, pp.1-65, Academic Press.

Schwartz, S.H. (1997) Values and Culture, Routledge, Washington.

Shin, H.H. and Soenen, L. (1998) 'Efficiency of working capital management and corporate profitability', Financial Practice and Education, Vol. 8, No. 2, pp.37-45.

Sullivan, D. (1994) 'Measuring the degree of internationalization of a firm', Journal of International Business Studies, Vol. 25, No. 2, pp.325-342.

Summers, B. and Wilson, N. (2003) 'Trade credit and customer relationships', Managerial and Decision Economics, Vol. 24, Nos. 6-7, pp.439-455.

Thomas, D.E. and Eden, L. (2004) 'What is the shape of the multinationality-performance relationship?', Multinational Business Review, Vol. 12, No. 1, pp.89-110.

Tran, H., Abbott, M. and Yap, C.J. (2017) 'How does working capital management affect the profitability of Vietnamese small- and medium-sized enterprises?', Journal of Small Business and Enterprise Development, Vol. 24, No. 1, pp.2-11.

Zahra, S.A., Ireland, R.D. and Hitt, M.A. (2000) 'International expansion by new venture firms: international diversity, mode of market entry, technological learning, and performance', Academy of Management Journal, Vol. 43, No. 5, pp.925-950. 